\title{
DGB $\mathrm{A}$ \\ International Entrepreneurship Review \\ 2020, Vol. 6, No. 3

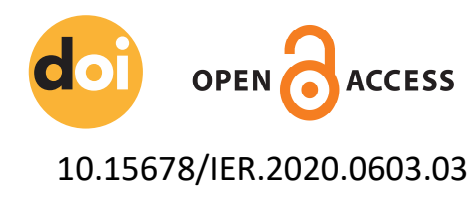 \\ Paradigm shift in the management of environmental and social challenges
}

\author{
Kenneth Chukwujioke Agbim
}

\begin{abstract}
A B S T R A C T
Objective: Despite the various approaches that have been adopted to control the negative consequences of environmental and social challenges, these consequences have persisted. Studies that have critiqued these challenges and the proffered solutions with the intent of offering a more encompassing and result oriented solutions are rare in the literature. Thus, based on the unprecedented dimensions the challenges have assumed, this study seeks to propose a holistic and more encompassing approach for managing the challenges.
\end{abstract}

Research Design \& Methods: The study adopts a research methodology that is based on a critical review and analysis of 25 related papers. The keywords employed to select the papers that were published between 1980 and 2020 are environmental challenges, social challenges and strategic development goals.

Findings: The approaches adopted so far to manage environmental and social challenges have not yielded the desired results. This is because: all the stakeholders are not involved in the formulation and implementation of the approaches; the approaches are formulated and implemented as though environmental and social challenges are not interrelated; the approaches vary among the different institutions, countries and regions; in some areas, the level of implementation is partial, while in others it is full.

Contribution \& Value Added: Environmental and social challenges are interrelated. As such the Environmental and Social Responsibility Network (ESRN) is proposed as a more encompassing approach since it will bring together all those who are directly and indirectly affected by the challenges.

\begin{tabular}{lll}
\hline Article type: & literature review \\
Keywords: & environmental entrepreneurship; social entrepreneurship; corpo- \\
JEL codes: & rate social responsibility; social innovation; NGO \\
\hline \multicolumn{2}{c}{ L31, O35, M14, P28, Q56 } & \\
\hline \multicolumn{2}{l}{ Article received: 10 July 2020} & Article accepted: 30 September 2020 \\
\hline
\end{tabular}

\section{Suggested citation:}

Agbim, K.C. (2020). Paradigm shift in the management of environmental and social challenges. International Entrepreneurship Review (previously published as International Entrepreneurship / Przedsiębiorczość Międzynarodowa), 6(3), 37-48. https://doi.org/10.15678/IER.2020.0603.03 


\section{INTRODUCTION}

The externalities of the production processes and consumption patterns in industrialized and developed countries of the world have been of great concern to individuals, organisations, governments and researchers. The same concern is being expressed about the poverty levels in developing and industrializing countries. Unarguably, while the affluence in the developed and industrialized economies have given rise to environmental challenges, the poverty in developing and industrializing countries have resulted to both environmental and social challenges. Consequently, the world is today confronted by unprecedented, complex, inter-related and interconnected global challenges. The most common of these challenges in the literature are environmental and social challenges.

These challenges include climate disruption, ozone depletion, over population, shortage of clean and accessible freshwater, ecosystem degradation, soil erosion, species decline and extinction, poverty, terrorism, and disease outbreak. Aside their harmful effects, these challenges have led to the emergence of opportunities for the development of areas of study, businesses, Non-Governmental Organizations (NGOs), institutes, and government ministries and agencies. In entrepreneurship, researchers and academics alike have invariably referred to these challenges using various terms namely, environmental business, ecological entrepreneurship, eco-enterprise, social entrepreneurship, sustainable entrepreneurship and green entrepreneurship (Armocida et al., 2020; Ogionwo, 2016; World Health Organization, 2020).

Thirty years after the World Commission on Environment and Development (WCED) coined the term "sustainable development", sustainability discourse within the public sphere has reached unprecedented levels (WCED, 1987). This cannot be said of the applied approaches so far. Even though so many opportunities have been discovered from the challenges, the end to the challenges themselves is yet to be achieved. Owing to the increasing level of poverty in most countries of the world and the unprecedented loss of natural resources; the true capital of any nation, it is therefore important to protect the environment, and to ensure that there are enough resources to fill the needs of both the current population and future generations in general and the poor in particular. This call has been triggered by: current researches in this area; challenges of enforcing environmental standards and laws by governments and NGOs; the high cost of waste management; information from individuals, households, communities, organisations, and the market place, the corruption bedevilling the implementation of government welfare programmes; and consequences of man's activities in the environment.

Researchers, policy makers, organisations, institutions and individuals have alluded to the persistence of these challenges amidst the proffered different solutions to both the environmental and social challenges. However, undoubtedly, the relatedness of these challenges and the proffered solutions are holistically not well understood in the public glare. Moreover, studies that have critiqued these challenges and the proffered solutions with the intent of offering a more encompassing and result oriented solutions are not only rare but have not been sufficiently brought to the fore. Upon this thrust and through the review of relevant literature, this paper: examines the typology, causes and effects of environmental and social challenges; examines the previous approaches adopted in managing environmental and social challenges; and makes a case for environmental and social responsibility network. 


\section{MATERIAL AND METHODS}

The research methodology adopted in this study is critical review and analysis of related literature. Papers published between 1980 and 2020 were considered in this study. These papers were generated from EBSCOhost database using "environmental challenges", "social challenges" and "strategic development goals" as keywords. Journal articles that did not focus on the causes, effects and responses or proffered solutions to the challenges were excluded. In all, 25 papers were selected and analysed in the study.

\section{LITERATURE REVIEW AND THEORY DEVELOPMENT}

\section{Typology of environmental and social challenges}

The major environmental issues that the world is facing today are degradation of air and land, water scarcity, deforestation, water pollution, climate change, ozone layer depletion, flooding and a decline in biodiversity. Most societies are dealing with social challenges such as food crises, unemployment, aging population, energy problems, health care challenges, poverty, terrorism, inequality, water scarcity, demographic shift, sexual violence, infrastructural inadequacies and economic challenges. There are also social challenges that are consequences of evolving lifestyles, social institutions and structures. These include hunger, illiteracy, epidemic and high rate of population growth (Ogionwo, 2016; WESS, 2013). More recently, coronavirus disease, codenamed COVID19 , confined the whole world to several months of compulsory holidays (Armocida et al., 2020; World Health Organization, 2020).

\section{Causes of environmental and social challenges}

Environmental and social challenges are caused mainly by natural forces and/or human influences (Ibimilua \& Ibimilua, 2014). These challenges result from imbalances, corruption and inequality (Dilys et al., 2011). Some of the factors behind environmental degradation are population growth, polluting technologies and overexploitation of ecosystems driven by unsustainable consumption and production patterns (UNEP, 2015). Climate change further damages the ecosystems and causes harmful effects on human livelihoods, agricultural productivity and food security (Dugarova \& Gülasan, 2017). As the global population increases and forest land is converted to agricultural and other uses, the world's forests continue to shrink, which causes loss of habitat for millions of species (FAO, 2015, 2016; Flower, 2006). Coronavirus disease that is plaguing the world originated from Severe Acute Respiratory Syndrome (SARS-CoV-2). However, the pandemic was first noticed in Wuhan, China (Gript, 2020; Human Rights Watch, 2020).

\section{Effects of environmental and social challenges}

The destruction of forests and vegetation cover could bring in its wake surface runoff that erodes the soil, siltation, floods, and local climatic change. People turn to new land and start the process all over again owing to the loss of soil fertility. Gases such as water vapour, carbon dioxide, ozone, methane and nitrous oxide together create a natural greenhouse effect. In addition, human activities such as cement production, land use conversion, gas flaring, fossil fuel combustion and bush burning are also contributing to 
the greenhouse gases. The resultant effect is climate change (IPCC, 2015). Climate change results in but not limited to flooding, cyclone, fires, hail, windstorm and permafrost melting. Climate change affects river flow, with serious implications for human settlements and agriculture. It affects human infrastructure, including transportation, energy demand, human settlements, the property insurance industry, and tourism (Flower, 2006). Climate change negatively impacts food security and economic growth. It also leads to poverty and increased displacement (IPCC, 2015).

The most affected part of the population by climate change are the least responsible for causing them and have limited capacity to cope with the consequences due to the lack of adequate infrastructure, public services and social protection systems. Climate change is contributing to various health threats such as malnutrition and outbreaks of infectious diseases, including malaria, diarrhoea (UNRISD, 2012, 2016) and more recently COVID-19. COVID-19 negatively impacts the social, economic, health and educational sectors, and economy of most countries. It poses untold fear and challenges to researchers and health-care providers. The highly contagious nature of the pandemic and the quarantine and social distancing measures adopted to curtail the spread has consequently made some parts of the environment isolated and deserted. Some of these places are being used for isolating those who tested positive and/or as burial ground for those who died of the pandemic (Armocida et al., 2020; Hargreaves et al., 2020; Rosenthal et al., 2020; Weir, 2020).

The role of poverty in deforestation is increased by overpopulation and the search for fuel wood by impoverished people (Anand, 2013). The constantly rising world population is shrinking forest reserves, and increasing air and water pollution. Crude oil spillage and some of the chemicals used in agricultural production are adversely affecting surface and underground water. Rapid population growth also strains school, medical and transportation systems. High population growth and urbanization is gradually reducing the ability of individuals to afford a balanced diet, decent shelter and clothing, and have access to clean water (Flower, 2006; Khan \& Chang, 2018). High level of consumption and unacceptable waste disposal practices pose grave risks. Many of those who bear these risks do not benefit in any way from the activities that produce the wastes (Anand, 2013).

As environmental and social challenges are growing, the cost for failing to solve them is increasing dramatically (OECD, 2011). Despite the negative consequences of these challenges, opportunities have been created from them. Aside the policy shifts and new partnerships that are prompted by responses to these challenges, the technological innovations that led to the use of cell phones for communication, the use of satellite imagery and improved telecommunication mapping systems (Gelsdorf, 2010) are some of the manifest positive evidences of these challenges as depicted by the previous approaches adopted in their management.

\section{Previous approaches adopted in the management of environmental and social challenges}

Strategies such as government ministries, global goals/strategies, NGOs, Corporate Social Responsibility (CSR) and social innovations have previously been adopted to tackle these problems. 


\section{The government ministries}

Until now, the thinking in some quarters is that the main actor to tackle environmental and social challenges is the governments through their respective ministries of environment and social development (Fujii \& Shintani, 2008). In the past, the responsibility for global challenges was placed in environmental ministries and institutions (WCED, 1987). These ministries and institutions had little or no control over the destruction caused by agricultural, industrial, urban development, forestry, and transportation policies and practices. However, the governments of various nations particularly in Africa have been able to initiate different policies, programmes and schemes to tackle environmental and social challenges. The governments achieved little or no success because most of the programmes usually do not get to the poor, underprivileged and marginalized. Moreover, the programmes were diverted from the target areas. In spite of the efforts of the government to preserve and keep the environment clean through its public environmental sanitation, water and waste management enterprises, environmental challenges are increasingly visible in the global south (Mbebeb \& Songwe, 2011; McFarlane, 2011).

\section{Global goals and strategies}

Environmental and social challenges cannot be implemented by government alone due largely to limitation in their management ability, and human and financial capital capacity (Moses \& Olokundun, 2014). The Millennium Development Goals (MDGs) and Strategic Development Goals (SDGs) came to be because governments of developing countries were unable to tackle environmental and social challenges like developed countries (Dugarova \& Gülasan, 2017; Shintani, 2011). The MDGs was aimed at reducing extreme poverty and other time-bound targets between 2000 and 2015 (United Nations Millennium Project, 2015). During the MDGs, substantial efforts were made to safe guard the environment. For instance, the threats to biodiversity which are caused by environmental degradation, pollution, overexploitation and acidification of ocean and seas are not confined to terrestrial ecosystems. Despite increasing actions to safeguard biodiversity, pressures on biodiversity have continued to grow (Laffoley \& Baxter, 2016).

Furthermore, substantial gains were made in various dimensions of poverty; child mortality rate, maternal mortality ratio and illiteracy rate (UN, 2015a). Despite these gains, a large proportion of people are still living in poverty across the regions, within countries, between urban and rural areas, and across households. In addition, in spite of the progress made in controlling the outbreak of infectious diseases, there was outbreak of Ebola virus disease (Dugarova \& Gülasan, 2017; WHO, 2016), the Middle East Respiratory Syndrome (MERS) outbreak in the Arabian Peninsula in 2012 and in South Korea in 2015, the 2009 influenza pandemic, and the 2015 Zika virus disease (WHO, 2015). Similar conclusions were also reached for all other MDGs (UN, 2015b, 2015c; World Bank Group, 2016). Consequently, the UN came up with a similar set of goals, SDGs 2030 agenda. Ending poverty and reducing inequalities are central to the 2030 agenda of the SDGs (UN, 2015a, 2015 c). The 2030 agenda also focuses on sustainable management of ecosystems and natural resources, sustainable consumption and production patterns, and urgent action on climate 
change. This is owing to their critical inter-linkages with other goals like eradicating poverty, reducing inequalities, and promoting inclusive and sustainable economic growth (Dugarova \& Gülasan, 2017).

\section{Non-governmental organisation}

Aside the contributions of governments, the MDGs and the SDGs in tackling these challenges, and the inability of the efforts of governments alone, and the pockets of failures recorded in the implementation of the MDGs, it is equally important to mention the contributions of NGOs. Mostashari (2005) notes that the term, "NGOs", was used in 1945 owing to the need by the UN to differentiate between participation rights for intergovernmental specialized agencies and those for international private organisations in its charter. Over the past decades, environmental NGOs' activity within the UN processes has intensified. Today, some of the innovations introduced by these NGOs are now a routine element of intergovernmental deliberations. NGOs have made several attempts in providing solutions to mankind challenges. However, in spite of the increasing number of both environmental and social NGOs all over the world, their impact with respect to tackling these challenges has not justified the increase. A case in point is the emergence of environmental NGOs in China. It has been reported that their emergence has not completely put paid to the environmental challenges in the country (Go et al., 2018; Wilson, 2017).

\section{Corporate social responsibility}

Corporate social responsibility (CSR) emerged based on the idea that business and society are interrelated, and that CSR contributes to corporate reputation and business performance. Thus, firms are globalising their activities and practices. This is evident in the increasing number of investments in different communities and underdeveloped countries by firms in developing and developed countries (Fujii \& Shintani, 2008; Weber, 2008). The inclusion of environmental protection as one of the dimensions of CSR (Sweeney \& Coughlan, 2008) is a pointer that like the social challenges, environmental challenges on a broader sphere should also concern organisations. Owing to corporate corruption, the practice and contributions of CSR to the society today, leaves much to be desired. Agbim (2018) asserts that an organisation is obligated to give to the society part of its profit. This is with respect to the impact of the negative externalities its activity makes on the society's ecosystem and facilities, and as a way of endearing itself to the society. However, corporate adherence to all the principles of CSR does not connote high level of corporate ethicality. The global corporate corruption and unethical corporate practices in corporate giants like Arthur Anderson, Enron, Worldcom, Tycon, Qwest, Adelphia and Satyam were perpetrated by the management hiding under the cover of CSR.

\section{Social innovations}

Social innovation entails changing certain human consumption pattern, income and lifestyle, creating an environmentally superior production processes, products and services (Singh \& Panackal, 2014), and creating enterprises with an environmental and social mission. Social innovation was adopted because it seeks to satisfy new needs not provided for at a defined period of time by the market. It equally seeks to improve the welfare of individuals and communities through social change (incremental or radical). Thus, it brings together different kinds of expertise, skills, and tangible and intangible assets. However, 
there is a systemic failure in fostering social innovation. This is because social innovation focuses on local challenges, thus excluding global challenges. Also, social challenges are multidimensional, multidisciplinary and multi-stake holding (e.g., universities, research institutes, private companies, government, civil society, citizens) in nature (OECD, 2011).

To reduce the rate of systemic failure, social norms were applied but failed to yield the much desired results due to the fact that social norms and values shift in complicated and often unexpected ways and respond to myriad forces at both lower and higher levels of social organisation. Policy instruments such as penalties, regulations, and incentives also failed on account of corruption (Carlson, 2001; House of Lords, 2011). Employment of education, ingraining of certain behaviours into all those concerned, introduction of micro-finance and social businesses, and all other measures applied by social and environmental NGOs, foundations, Civil Society Organisations (CSOs), religious organisations and philanthropists have not yielded the much desired outcomes (Christakis \& Fowler, 2009; OECD , 2011). The persistence of these problems is a clear proof that man is yet to find the methods and tools with which to apply the interdependence in solving these problems. This suggests that the challenges can be tackled through a network structure.

\section{The case for environmental and social responsibility network}

Previous approaches adopted and implemented to manage environmental and social challenges are fragmented and individualistic. That is, the approaches are being formulated and implemented without involving all the stakeholders. The approaches are formulated and implemented as though environmental and social challenges are not interrelated. Even though the challenges are global in nature, the different institutions, countries and regions formulate and implement varying approaches to tackle the challenges. Again, with respect to implementation, while some institutions, countries and regions embark on full implementation, others carry out partial implementation. This is owing to corrupt practices such as diversion of the interventions by the institutions saddled with the responsibility. As such, these approaches have not helped to control the challenges.

Environmental challenges are complex and interlinked, not only in themselves but also with social challenges. The solutions for one environmental or social challenge can lead to or create new environmental or social challenges (Bierbaum et.al, 2018). For example, global warming and land degradation, and their attendant consequences of damages to firms, homes and arable lands for agriculture can create job losses or unemployment, displacements or loss of shelter, health challenges, hunger and poverty. Conversely, poverty can drive a person into illegal felling of trees for the purpose of gathering firewood to sell in the market. Such person may as well engage in tree burning in other to make charcoal which can be sold as cooking fuel. Thus, such acts can contribute to land degradation, deforestation and ozone depletion.

From the foregoing, it can be deduced that acting alone, spirited individuals, philanthropists, companies through their CSR, governments or states through their ministries of environment and social development, and institutions can not completely tackle these challenges. In addition, the pockets of achievements by these individuals and organisations have not been sustained. Consequently, there is need for a new approach that is born out of a new idea and concept. The failure of the previously proffered solutions can be linked to the absence of collaboration among the stakeholders. The collaboration brings together the objectives of different agencies, enhances synergies, untangles complexity, gives feedbacks and builds whole-system resilience. To address the intercom- 
nectedness between environmental and social challenges requires systems thinking; the interactions of all the components of the system. It requires the interactions of all the stakeholders (Bierbaum et al., 2018). The term that fits this description is "network". Specifically, the individuals and organisations (or institutions) that have hitherto acted alone in tackling these challenges must be actors in this association. This should include all those contributing to the environmental and social challenges, those affected by the network challenges, those who feel they are not affected, owner-managers of both environmental and social NGOs, the eco-preneurs and socio-preneurs, the philanthropists, manufacturing firms, institutions (local, national and international) and the governments (local, state, federal).

Governments should be involved because they make the largest impact on the environment. By this they are supposed to take the lead in tackling these challenges. However, this is not so going by the GlobeScan poll of experts; of all the efforts by businesses, NGOs and governments, governments efforts in this regard are ranked last (Prahalad \& Hart, 2002). NGOs should be made to actively participate in the joint effort to tackle these challenges owing to their previous roles in environmental activism (McGann \& Johnstone, 2006), social and community development. NGOs carry out their projects more efficiently and at lower costs than government agencies and work with firms to enhance their CSR (Nikkhah \& Redzuan, 2010).

Ecopreneurs and ecopreneurships promote greener firms and economies, generate decent jobs, and fight to eliminate persistent poverty (Choi \& Gray, 2008; UNEP, 2011). Environmental entrepreneurships disseminate in the market place information that help make consumers more aware of their environment. The operations of ecopreneurships are closely geared to saving, nurturing or restoring the environment (Menon, 2017). Social entrepreneurs and entrepreneurships focus on the identification of social challenges and the adoption of innovative and entrepreneurial approaches targeted at proffering short and long term solutions (OECD, 2011). Social entrepreneurs always seek to eradicate needs rather than respond to them. Social entrepreneurs facilitate the surmounting of social challenges (El Ebrashi, 2013). The dynamism of social entrepreneurship is undoubtedly a spring board for overcoming social challenges (Moses \& Olokundun, 2014).

Network relationships at domestic and international level are effective in controlling environmental challenges (Gelsdorf, 2010; Ibimilua \& Ibimilua, 2014; Karaduman, 2014; Khan \& Chang, 2018). Networks promote the use of the old and new or social media for learning and reacting to issues such as environmental and social challenges. Networking via social media helps to generate resources that encourages environmental activism and enhances the creation of entrepreneurship (Shane \& Venkataraman, 2000). The quality of a network influences the efforts of the network in tackling social and environmental challenges. Similarly, the quality of a network depicts the composition, exposure and connections of the actors. Social networks can profoundly affect human behaviour, which is the primary force driving environmental change (Baker, 2000).

\section{CONCLUSIONS}

All the efforts of individuals, the academia, organisations, NGOs and governments to manage the global environmental and social challenges have not yielded the much desired end. Moreover, in few cases where collaborative approaches were applied, the intervention was not encompassing. The proper management of these challenges is needed most now 
that the untold adverse consequences are globally affecting both the rich and the poor. Conversely, the poor and the rich will be better off if the challenges are well managed. Consequently, this study established that Environmental and Social Responsibility Network (ESRN) is a more encompassing and appropriate intervention proposed to manage environmental and social challenges. The ESRN approach entails bringing all those who are directly and indirectly affected by these challenges (e.g., spirited individuals, community leaders, CEOs of organisations, directors of NGOs, heads of governments and heads of institutions) to form networks at community, State, National and International levels. This approach is justified on the ground that these challenges are intertwined, interrelated and interdependent as such does not require a fragmented and individualistic approach. It needs to be tackled jointly by every person and organisation concerned.

This paper extends existing literature from the previous fragmented and individualistic approaches to tackling these global challenges to ESRN; a more holistic and encompassing approach. The findings of this study will spark off debate among spirited individuals, the intelligentsia, development practitioners, scholars and researchers that will generate the modus operandi for ESRN in all the suggested operational levels. Researchers will also be inspired to investigate why specific environmental and social challenges have persisted. It will equally motivate all those who are directly and indirectly affected by the challenges to be more committed to ending or reducing them to the barest minimum. The conceptual nature of this paper on its own is a limitation. To make the views expressed in the paper more holistic and concrete, it should be contrasted with empirical survey using triangulation method.

\section{REFERENCES}

Agbim, K.C. (2018). Effect of ethical leadership on corporate governance, performance and social responsibility: A study of selected deposit money banks on Benue State, Nigeria. Informing Science: International Journal of Community Development \& Management Studies, 2, 19-35.

Anand, S.V. (2013). Global environmental issues. Open Access Scientific Reports, 2(2), 1-9. doi:10.4172/scientificreports.632

Armocida, B., Formenti, B., Ussai, S., Palestra, F., \& Missoni, E. (2020). The Italian health system and the COVID-19 challenge. Lancet Public Health, 1. doi:10.1016/S2468-2667(20)30074-8

Baker, W.E. (2000). Achieving success through social capital: Tapping the hidden resources in your personal and business networks. Jossey-Bass.

Bierbaum, R., Cowie, A., Barra, R., Ratner, B., Sims, R., Stocking, M., Durón, G., Leonard, S., \& Whaley, C. (2018). Integration: To solve complex environmental problems. Scientific and Technical Advisory Panel to the Global Environment Facility. UN.

Carlson, A.E. (2001). Recycling norms. California Law Review, 89, 1231-1300.

Choi, D.Y., \& Gray, E.R. (2008). The venture development processes of "sustainable" entrepreneurs. Management Research News, 31(8), 558-569.

Christakis, N.A., \& Fowler, J.H. (2009). Connected: The surprising power of our social networks and how they shape our lives. Little, Brown and Company.

Dilys, R., David, T., Jessica, S., Matt, W., \& Joanna, E. (2011). Biodiversity and poverty: Ten frequently asked questions - Ten policy implications. International Institute of Environment and Development.

Dugarova, E., \& Gülasan, N. (2017). Challenges and opportunities in the implementation of the Sustainable Development Goals. United Nations Development Programme and United Nations Research Institute for Social Development. 
El Ebrashi, R. (2013). Social entrepreneurship theory and sustainable social impact. Social Responsibility Journal, 9(2), 188-209. doi.:10.1108/SRJ-07-2011-0013

FAO (Food and Agriculture Organization of the United Nations) (2015). FAO and the 17 Sustainable Development Goals. FAO.

FAO (Food and Agriculture Organization of the United Nations) (2016). Global forest resources assessment 2015: How are the world's forests changing? FAO.

Flower, L. (2006). Environmental challenges in the 21st century. AU J.T., 9(4), 248-252.

Fujii, T., \& Shintani, D. (2008). Asian CSR and Japanese CSR. JUSE-press.

Gelsdorf, K. (2010). Global challenges and their impact on international humanitarian action. UN Office for the Coordination of Humanitarian Affairs (OCHA). Occasional Policy Briefing Series No. 1. Policy Development and Studies Branch (PDSB). Retrieved December 10, 2018 from https://docs.unocha.org/sites/dms/Documents/Global_Challenges_Policy_Brief_Jan10.pdf

Go, K., Suzuki, M., \& Qu, X.X. (2018). Trial by fire: A Chinese NGO's work on environmental health litigation in China. Retrieved December 10, 2018 from https://www.wilsoncenter.org/publication/trial-fire-chinese-ngos-work- environmental-health-litigation-china.

Gript (2020, March 31). 60 minutes: Wuhan whistle-blower Dr Ai Fen "has disappeared". Gript. Retrieved November 25, 2020 from gript.ie/60-minutes-wuhan-whistle-blower-dr-ai-fen-has-disappeared/ on 15 June 2020.

Hargreaves, S., Kumar, B. N., McKee, M., Jones, L., \& Veizis (2020). Europe's migrant containment policies threaten the response to covid-19. Business Management Journal, 368, 1-2. doi: 10.1136/bmj.m1213

House of Lords (2011). Behaviour change. House of Lords, Science and Technology Select Committee. HL Paper, No. 179.

Human Rights Watch (2020). Human rights dimensions of COVID-19 response. Retrieved November 25, 2020 from https://www.hrw.org/news

Ibimilua, F.O., \& Ibimilua, A.F. (2014). Environmental challenges in Nigeria: Typology, spatial distribution, repercussions and way forward. American International Journal of Social Science, 3(2), 246-253.

IPCC (2015). Climate change 2014: Impacts, adaptation and vulnerability (part A). Global and sectorial aspects. Contribution of working group II to the fifth assessment report of the intergovernmental panel on climate change. Cambridge University Press.

Karaduman, I.C. (2014). Global challenges for the world. Obronność Zeszyty Naukowe, 2(10), 45-58.

Khan, M.I., \& Chang, Y. (2018). Environmental challenges and current practices in China: A thorough analysis. Sustainability, 10(2547), 1-20. doi: 10.3390/su10072547

Laffoley, D., \& Baxter, J.M. (Eds.) (2016). Explaining ocean warming: Causes, scale, effects and consequences. International Union for Conservation of Nature and Natural Resources.

Mbebeb, F.E., \& Songwe, O. (2011, Dec. 5-8). Promoting ecopreneurship behaviours in sustainable resources exploitation: Greening youths for green business in Cameroon [Conference session]. International Conference on Sustainable Development of Natural Resources in Africa, UNUINRA, Accra, Ghana.

McFarlane, C. (2011). Learning the city: Knowledge and translocal assemblage. John Wiley and Sons.

McGann, J., \& Johnstone, M. (2006). The power shift and the NGO credibility crisis. International Journal of Not-for-Profit Law, 8(2), 65-77.

Menon, R.B. (2017). Students' attitude towards ecopreneurship. Commerce Spectrum, 4(2), 1-3. 
Moses, C.L., \& Olokundun, M.A. (2014). Social entrepreneurship: An effective tool for meeting social challenges and sustainable development. Entrepreneurship and Innovation Management Journal, 2(3), 158-169.

Mostashari, A. (2005). An introduction to non-governmental organizations (NGO) management. Iranian Studies Group at MIT.

Nikkhah, H.A., \& Redzuan, M.B. (2010). The role of NGOs in promoting empowerment for sustainable community development. Journal of Human Ecology, 30(2), 85-92.

OECD (Organisation for Economic Co-operation and Development) (2011). Divided we stand: Why inequality keeps rising. OECD.

Ogionwo, T. (2016). Social problems and the rise of terrorism in Nigeria: Implications for international social work practice. Thesis submitted to Department of Social Work and Psychology, University of Gavle.

Prahalad, C.K., \& Hart, S.L. (2002). The fortune at the bottom of the pyramid. Strategy+Business, 26, (1), 1-14.

Rosenthal, D. M., Ucci, M., Heys, M., Hayward, A., \& Lakhanpaul, M. (2020). Impacts of COVID-19 on vulnerable children in temporary accommodation in the UK. Lancet Public Health, 1-2. doi: 10.1016/S2468-2667(20)30080-3

Shane, S., \& Venkataraman, S. (2000). The promise of entrepreneurship as a field of research. Academy of Management Review, 25(1), 217-226.

Shintani, D. (2011). The role of business actor for social innovation from CSR perspectives. In OECD, Fostering innovation to address social challenges, workshop proceedings (pp. 65-68). OECD.

Singh, A., \& Panackal, N. (2014). Youth ecopreneurship: A key for success of first generation entrepreneurs. Annual Research Journal of SCMS, Pune, 2(1), 1-13.

Sweeney, L., \& Coughlan, J. (2008). Do different industries report corporate social responsibility differently? An investigation through the lens of stakeholder theory. Journal of Marketing Communication, 14(2), 113-124.

UN (2015a). We can end poverty: Millennium Development Goals (MDGs) and beyond2015. Retrieved November 10, 2018 from http://www.un.org/millenniumgoals/

UN (2015b). The Millennium Development Goals Report 2015: Regional backgrounder: Western Asia. DPI/2594/5 E. UN Department of Public Information.

UN (2015c). Transforming our world: The 2030 agenda for Sustainable Development (A/RES/70/1). UN.

UNEP (United Nations Environmental Programme) (2011). Towards a green economy: Pathways to sustainable development and poverty eradication - A synthesis for policy makers. Retrieved June 15, 2018 from http://www.unep.org/greeneconomy

UNEP (United Nations Environment Programme) (2015). Sustainable consumption and production: A handbook for policymakers: Global edition. UNEP.

United Nations Millennium Project (2015). Who they are. Retrieved November 11, 2018 from http://www.unmillenniumproject.org/goals/

UNRISD (United Nations Research Institute for Social Development) (2012). Social dimensions of green economy. UNRISD Research and Policy Brief 12. Geneva: UNRISD.

UNRISD (United Nations Research Institute for Social Development) (2016). Policy innovations for transformative change: Implementing the 2030 agenda for sustainable development. UNRISD.

WCED (World Commission on Environment and Development) (1987). Our common future. Oxford University Press. 
Weber, M. (2008). The business case for corporate social responsibility: A company-level measurement approach for CSR. European Management Journal, 26(4), 247-261. doi.: 10.1016/j.emj.2008.01.006

Weir, K. (2020). Seven crucial research findings that can help people deal with COVID-19. Retrieved November 25, 2020 from apa.org/news/apa/2020/03/covid-19-research-findings

WESS (2013). Sustainable development challenges. Retrieved December 10, 2018 from http://www.un.org/en/development/desa/policy/wess/wess_current/wess2013/WESS2013

WHO (World Health Organization) (2015). Health in 2015: From MDGs, Millennium Goals to SDGs, Sustainable Development Goals. WHO.

WHO (World Health Organization) (2016). Ebola Situation Report: March 30, 2016. WHO. Retrieved December 10, 2018 from http://apps.who.int/ebola/current-situation/ebola-situation-report30-march-2016

Wilson, S. (2017). China's NGO regulations and uneven civil society development. Retrieved December 10, 2018 from http://theasiadialogue.com/2017/02/15/chinas-ngo-regulations-and-uneven-civil-society- development/

World Bank Group (2016). Global Monitoring Report 2015/2016: Development Goals in an era of demographic change. World Bank Group and International Monetary Fund.

World Health Organization (WHO) (2020). Coronavirus. Retrieved November 25, 2020 from https://www.who.int/health-topics/coronavirus\#tab=tab_1

\section{Author}

\section{Kenneth Chukwujioke Agbim}

Doctoral candidate in the Department of Management, University of Nigeria, Enugu, Nigeria. He has M.Sc. in Development Studies, MBA in Management and M.Sc. in Management. His research interests are in the areas of strategic entrepreneurship, family business development and business ethics.

Correspondence to: kennethagbim2012@gmail.com

ORCID (i) http://orcid.org/0000-0002-9204-3387

\section{Copyright and License}

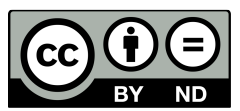

This article is published under the terms of the Creative Commons

Attribution - NoDerivs (CC BY-ND 4.0) License

http://creativecommons.org/licenses/by-nd/4.0/

Published by Cracow University of Economics - Krakow, Poland 